\title{
THERMAL COMFORT AT THE STREET CORRIDOR AROUND PUBLIC PLACES, CASE STUDY ALUN-ALUN MALANG
}

\section{Erna Winansih}

\section{Antariksa} \\ Surjono
}

Amin Setyo Leksono
Post graduate student of Environmental Science, Brawijaya University, Malang, Indonesia e-mail: erna.winansih@unmer.ac.id

Lecturer of Architecture Department, Brawijaya University, Malang, Indonesia

Lecturer of Urban and Regional Planning Department, Brawijaya University, Malang, Indonesia

Lecturer of Biology Department, Brawijaya University, Malang, Indonesia

Received: September $1^{\text {st }} 2015$; Accepted: September $14^{\text {th }} 2015$; Available Online: December $31^{\text {st }} 2015$ DOI: http://dx.doi.org/10.18860/jia.v3i4.3102

\begin{abstract}
Malang as the second largest city in East Java province become crowded recently. The congestion almost happens everyday. The scenery of the street corridor is full of iron stacks. It is said that Malang city is less comfortable and less walkable. The decrease of this environment encourages conduct the study (Q.S. 16:90, Q.S. 96:1-5, Q.S. 30:41). The study aimed to analyze the thermal comfort at pedestrian ways around Malang city squares, the street corridor of Merdeka Alun-Alun (MAA) and the Tugu Alun-Alun (TAA). The temperature and relative humidity were measured by multinorm instrument. The THI (Temperature Humidity Index) method was used to analyze the thermal comfort. The results showed that the THI average at TAA $(27)$ were more comfortable than at MAA $(27,5)$. The south side of the MAA corridor became the most comfortable with the THI value of 26,4 , which the side covered by trees canopy (Q.S. 7:58). It needs to conduct next research (Q.S. 13:11), because of the change of the activities in these street corridors.
\end{abstract}

Keywords: thermal comfort, THI, pedestrian way, street corridor

\section{Introduction}

Streets trigger the rapid change of land cover because of the growth and development of the city and tend to lead the decrease of the quality of the city environment [1][2][3]. Malang city as the second largest city in East Java Province shows the rapid growth and nowadays becomes more crowded and less comfortable [4][2][5]. It seems that urban heat island have occurred and causes the discomfort in thermal ways [Q.S. 16:90, Q.S. 96:1-5, Q.S. $30: 41],[6][7][8][9][10]$

\section{Literature Review}

Thermal comfort can be defined from different views. There are three principals to define the term thermal comfort. Those are the psychological, thermophysiological approaches and heat balance of human body [11]. Psychologically thermal comfort is the mind condition that indicates the thermal circumstances' satisfaction [12]. The condition is difficult to conclude because it depends on each person, but it is important, especially for outdoor. Thermophysiologically, thermal comfort is based on the heat process of the thermal receptor on the skin and hypothalamus. From the heat balance of the body view, the thermal comfort is reached when the heat flow of the body is balance between the inlet and outlet and the sweat at the comfort range. Those processes depend on the body metabolism. The average temperature of the body plays an important role on the two latter definitions [11]. The thermal comfort is affected by climate variables (air temperature, mean radiant temperature, dewpoint or relative humidity and the wind flow), personal variables (clothes and activities, adaptation and acclimatization) [13].

Indoor thermal comfort is different from the outdoor [14][15][16][17]. Comparing with the study of indoor thermal comfort, the outdoor thermal comfort 
studies still need to be increased. The standards of indoor thermal comfort have already existed, such as ASHRAE, EN 15251, EN ISO 7730 and so forth. Recently the outdoor thermal comfort studies have been increasing [14][15][11][18][16][19]. Some indoor thermal comfort indexes are able to measure outdoor thermal comfort [11]. But these standardizations should not be suitable in all places, because of the differences in climate and built environment conditions [18][16][20].

\section{Previous Studies}

Outdoor thermal comfort studies had been done using various approaches and methods, there are even more than a hundred indices to measure the outdoor thermal comfort. These indices include PMV (Predictive Mean Vote), PET (Physiologically Equivalent Temperature, ET (Effective Temperature), SET (Standard Effective Temperature), CET (Corrected Effective Temperature), ITS (Index of Thermal Stress), DI (Discomfort Index) and so forth [14][3]. Some studies of outdoor thermal comfort in humid tropical climate are listed below:

1. Johanson, 2006, measured the outdoor thermal comfort using PET method: The influence of urban design on outdoor thermal comfort in the hot, humid city of Colombo, Sri Lanka [21]

2. Sangkertadi, 2006, measured outdoor thermal comfort using PMV and DISC (Discomfort) methods: The Role of Wind Velocity on Increasing Human Thermal Comfort in Hot and Humid Environment [22]

3. Sangkertadi, 2012, studied the standardization of ISO 7730 [23]

4. Hadi, Rohman. Arthawalila, Komang. Gunadi, I Gusti Alit., 2012. Evaluation Comfort Index City Park (Puputan Badung IGN Made Agung yard) Denpasar, Bali, using THI method $(\mathrm{THI}=0,8 \mathrm{Ta}+$ $(\mathrm{RH} \times \mathrm{Ta}) / 500)$ [24]

5. Setiawati, P, 2012: The Green Open Space Effect to the Micro Climate, Case Study: Kebun Raya Cibodas, Indonesia, using the Laurie THI method [20].

6. Bantacut T: Iqbal M, 2012, The Effect of $\mathrm{CO} 2$ Antropogenic Emission and The Decrease of Green Open Space Area to the THI value in Bogor City Indonesia, using Nieuwolt method, THI=0,8 $\mathrm{Ta}+(\mathrm{RH} \times \mathrm{Ta}) / 500)$. The THI threshold 20-27 [8].

7. Andriono F, 2013, Dynamic Of Green Open Space And Temperature Humidity Index In Malang City, Indonesia, using THI method, comfort range 1926 [4].

\section{Materials and Methods}

Research methodology consists of data compilation and analysis. The thermal data were measured by multinorm instrument. The instrument had been used to measure the temperature and relative humidity at about the center point of the side of pedestrian ways around street corridors (four points at the sides of MAA and five points at the sides of TAA) during the peak hours (11.30 - 15.30) for four days. The Temperature Humidity Index (THI) method analyzed the thermal data and used the excel program to calculate the $\mathrm{THI}$ formula: $\mathrm{THI}=$ 0,8 $\mathrm{Ta}+(\mathrm{RH} \times \mathrm{Ta}) / 500 ;(\mathrm{Ta}=$ Air temperature in $\mathrm{C}$, $\mathrm{RH}=$ Relative Humidity in \%).

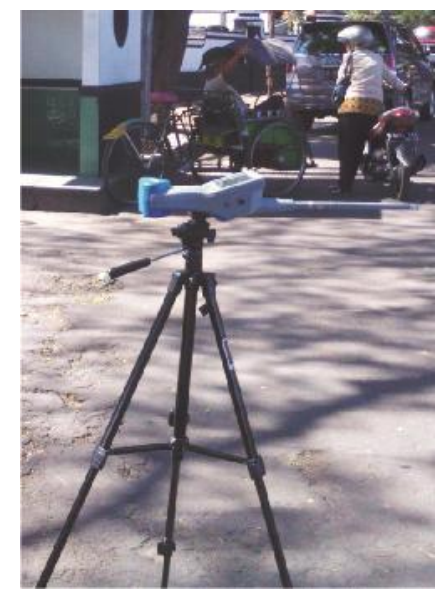

Figure 1. The multinorm instrument with temperature and relative humidity probes (source: researcher documentation).

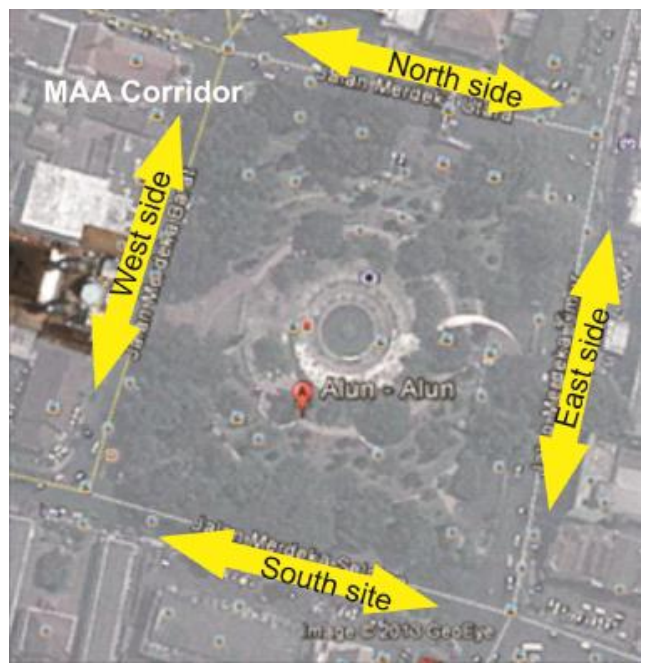

Figure 2. The MAA street corridor (Source: google earth 2014 and modified by author) 


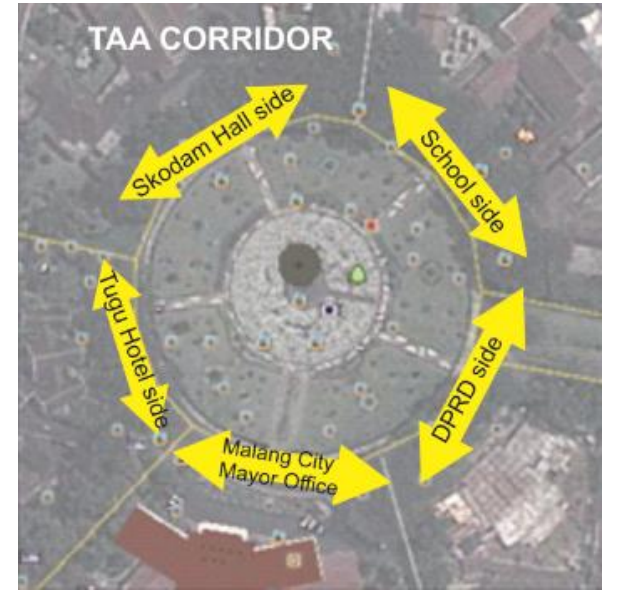

Figure 3. The TAA corridor (source: google earth 2014 and modified by author)

\section{Results}

The results showed that all of the sides of street corridors of MAA and TAA were over 26. Depending on the thermally comfortable $\mathrm{THI}$ of Laurie [25], the comfort range is 20-26, THI of Nievwolt is 19-26 [4] and Rushayati is 21-27 [26]. According to the Rushayati THI, the Indonesian researcher, the thermal comfort THI starts from 21 to 27 , it meant that some sides of the MAA and TAA reached the thermally comfortable corridors. The average $\mathrm{THI}$ at the MAA corridors was 27,5 and at the south side of MAA showed the THI at the lowest: 26,3 so it would be the most thermally comfortable among MAA and TAA corridors. The most thermally uncomfortable occurred on the east side of MAA corridor, THI value: 28. The average THI at TAA was 27. The highest value at TAA corridors happened at side in front of the Malang city mayor office, it showed THI value of 27,9 . The lowest THI value of the TAA corridor showed 26,4 at the side in front of the Tugu hotel.

Table 1. The THI values at the MAA and TAA corridors

\begin{tabular}{|c|c|c|c|c|c|c|c|c|c|}
\hline \multirow{3}{*}{$\begin{array}{l}\text { Thermal } \\
\text { comfort } \\
\text { indicators }\end{array}$} & \multicolumn{9}{|c|}{ Value } \\
\hline & \multicolumn{4}{|c|}{ MAA street corridor } & \multicolumn{5}{|c|}{ TAA street corridor } \\
\hline & NS & ES & SS & WS & Sch S & DPRDS & MCMO S & THS & SHS \\
\hline $\begin{array}{l}\text { Temperature } \\
\text { (Celsius } \\
\text { degree) }\end{array}$ & 29 & 31 & 28,45 & 31,225 & 28,75 & 29,925 & 30,55 & 28,425 & 28,9 \\
\hline $\begin{array}{l}\text { Relative } \\
\text { humidity (rh } \\
\text { percent) }\end{array}$ & 62,85 & 57,725 & 63,525 & 54,075 & 61,775 & 59,425 & 56,55 & 64,55 & 61,075 \\
\hline THI & 26,9 & 28,4 & 26,3 & 28,3 & 26,6 & 27,5 & 27,9 & 26,4 & 26,7 \\
\hline
\end{tabular}

\section{Discussion}

The most thermally comfortable corridor was the one along the south side of the MAA. This side of the MAA corridor almost covered by the shadow of the trees along both sides of the corridor. The shade and the shadow that cast along the corridor gave space psychologically. That's why there were kind of activities occurred in this south side. The tree shadiness gave the comfortable ambience (Q.S. 7:58).

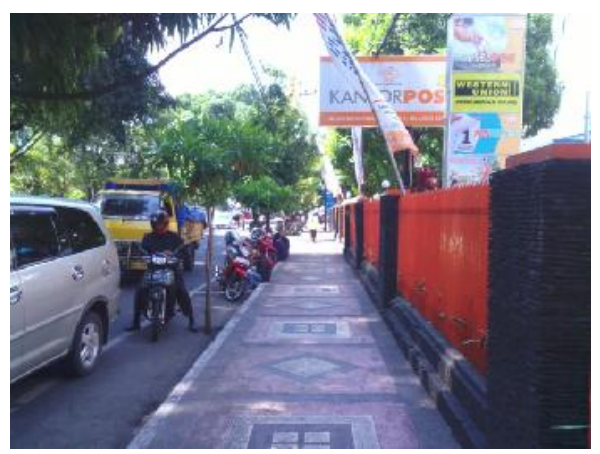

Figure 4 . The south side of MAA corridor, the picture taken from west (source: researcher documentation) 


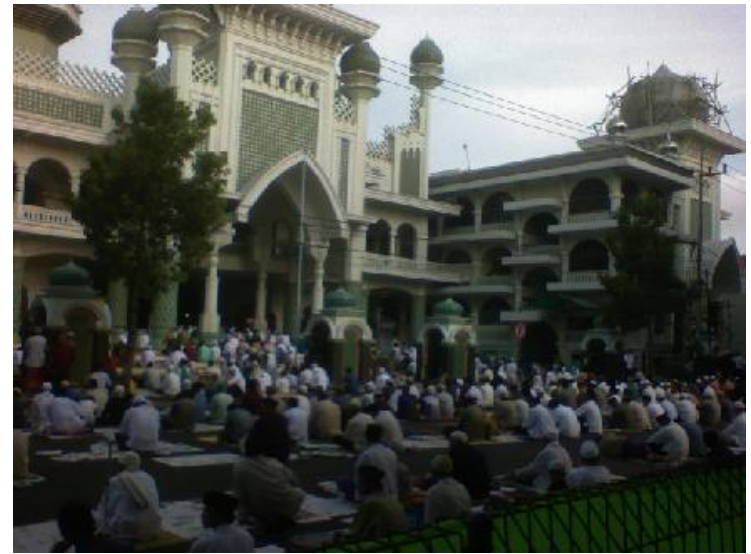

Figure 5. The west side corridor of MAA as the extension of the Jami Mosque's porch afford the praying activity every Friday, even MAA and all the corridors surroundings become the court of led praying (source: researcher's documentation).

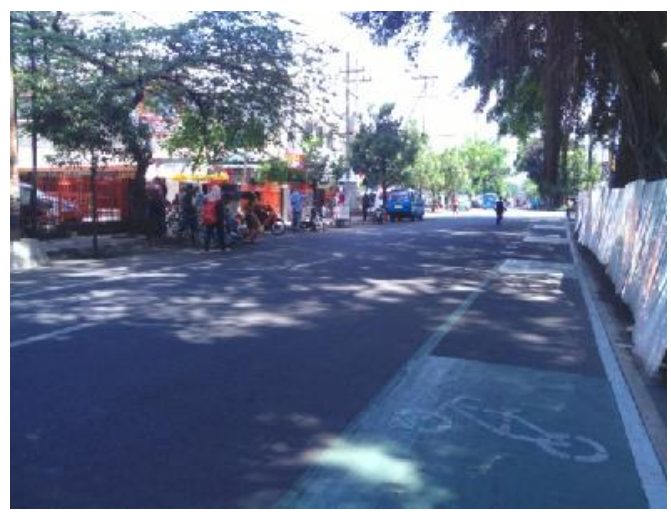

Figure 6 . The south side of MAA corridor, the picture taken from the east (source: researcher documentation).

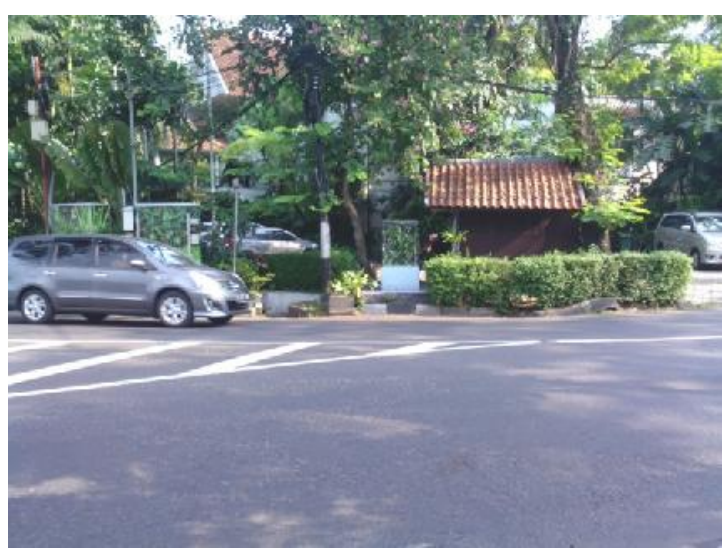

Figure 7. The Tugu Hotel side of TAA (source: researcher's documentation).

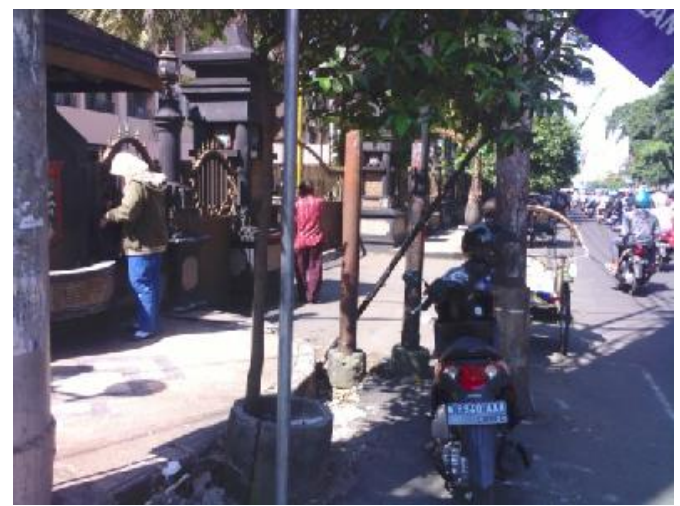

Figure 8 . The most thermally uncomfortable side of MAA at the east side (source: researcher's documentation).

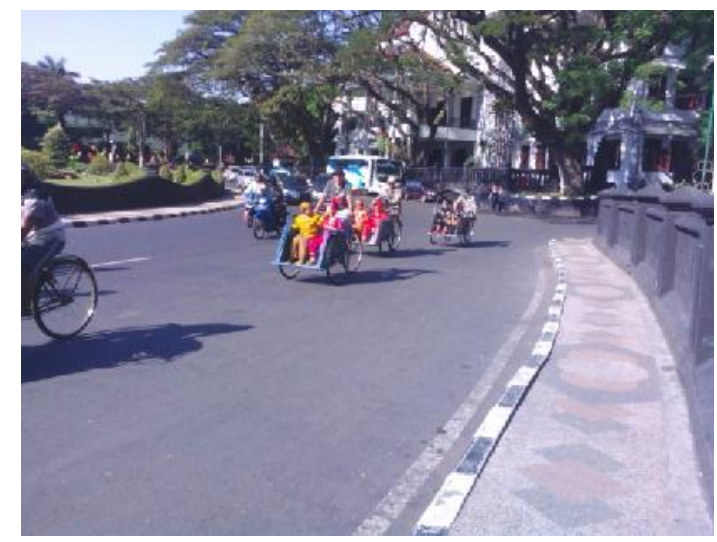

Figure 8. The most thermally uncomfortable side of TAA at Malang City Mayor Office side (source: researcher's documentation).

The lack of canopy that could cast a shadow caused the thermally uncomfortable pedestrian way. A few pedestrians did the walking on this side and there're almost no activities here. The bright sun shone the corridor and the air temperature measured increased because the radiation of the solar. Although the surrounding of the pedestrian ways was clean, but the solar radiation seemed to be 'hazardous' because of the heat perceived, and at the THI value showed the highest at TAA $(27,9)$. The value indicated the thermally uncomfortable. The street corridor with no shadow emerged the urban heat island, because the road was exposed to the sunlight and solar radiation. The structure of the city and anthropogenic activities affected the increase of urban heat island at the central business district [7][9][10]. 


\section{Conclusion}

This paper studied the THI value of the street corridors where pedestrians did the walking. The pedestrian ways which had the psychological space effects were rich in activities. The conclusions are listed below:

1. The most thermally comfortable corridor was covered by the canopy of the trees, so the shadow and shade that cast on the surface of the street corridor would be the barrier of the sun radiation. The sun radiation affects the air temperature, and increase the temperature.

2. The amount of activities that occurred in the shadowed corridor were rich, as opposite to the opened corridors with no canopy.

3. The research should be continued to study the relationship between the volume or area of the trees or green cover to the thermal comfort parameters.

The measurement is done in this research limited to the data compiled during four days, that's why need to be elaborated on the next research (Q.S. 13:11) in order to give the more significant results.

\section{References}

[1] K. Monam, A. Rückert, The Dependence of Outdoor Thermal Comfort on Urban Layouts. Universitätsverlag der TU Berlin, Universitätsbibliothek, Fasanenstr. 8810623 Berlin, 2013.

[2] P. Newman, "No Title," in International Conference, ICPEU, PWK, Universitas Brawijaya Malang., 2015.

[3] J. Najoan, "Evaluasi penggunaan Tanaman lansekap di Taman Kesatuan Bangsa (TKB), Pusat kota Manado," J. Sabua, vol. 3, no. 1, pp. 9-18, 2011.

[4] Andriono, Ferry., Hanafi, Imam., Yanuwiadi, Bagyo., Soemarno., "Dynamic Of Green Open Space And Temperature Humidity Index In Malang City," Int. J. Eng. Sci., vol. 2, no. 3, pp. 26-32, 2013.

[5] K. Olesen, BW. Parsons, "Introduction to thermal comfort standards and to the proposed new version of EN ISO 7730," Elsevier Sci. B.V., 2002.

[6] A. Sugiyono, "Global Warming Countermeasures in Sector Energy Users," J. Weather Modif. Sci. Technol. 7, vol. 2, pp. 15-19, 2006.

[7] A. C. Achsan, "Green Open Space Planning in Bogor by Using Dynamic Systems Approachle," Bogor Agricultural University, 2009.

[8] M. Bantacut, Tajuddin., Iqbal, "Estimation of
Temperature Humidity index Value Based on $\mathrm{CO} 2$ Antrophogenic Emission and Existing Green Open Space Development on Bogor City by Dynamic System Approach," EJournal Agroindustri Indones., 2012.

[9] X. Li, F., Wang, R., Liu, X., Zhang, "Urban Forest in China: Development Patterns, Influencing Factors and Research," Int. J. Sustain. Dev. World Ecol., vol. 12, no. 2, p. 197, 2005.

[10] M. Wicahyuni, Suksesi,.Sasongko, Setibudi., Izzati, "Pulau Bahang Kota (URBAN HEAT ISLAND) di Yogyakarta, Hasil Interpretasi Citra langit," in Prosiding Seminar Nasional Pengelolaan Sumberdaya Alam dan Lingkungan, 2013.

[11] P. Hoppe, "Different aspects of assessing indoor and outdoor thermal comfort," Energy Build., vol. 34, 2002.

[12] A. S. 55-2013, Thermal Environmental Conditions for Human Occupancy. 2013.

[13] A. S. Ghazizadeh, S. Neda, Monam, Alireza, \& Mahmoodi, "The impact of the architectural design in the thermal comfort of the outdoor spaces in residential complexes," 2010.

[14] E. K. Eric Johansson, Sofia Thorsson, Rohinton Emmanuel, "Instruments and methods in outdoor thermal comfort studiesthe need for standardization, urban climate," vol. 10, pp. 346-366, 2014.

[15] T. Honjo, "Thermal Comfort in Outdoor Environment," Glob. Environ. Res., pp. 4347, 2009.

[16] E. Santoso, "Kenyamanan Termal Indoor pada Bangunan di Daerah Beriklim Tropis Lembab," Indones. Green Technol. J., vol. 1, no. 1, 2012.

[17] T. Subadio, "Kajian Lansekap Koridor Jalan," ITS Surabaya, 2011.

[18] M. Monteiro, LM. Alucci, "Thermal Comfort Index for the Assessment of Outdoor spaces in Subtropical Climates," in The seventh International Conference on Urban Climate, 2009.

[19] M. Mohan, "Dynamics of Urbanization and Its Impact on Land-Use/Land-Cover: A Case Study of Megacity Delhi Subhan K. Pathan2, Kolli Narendrareddy1, Anurag Kandya1, Sucheta Pandey3 , Centre for Atmospheric Sciences, Indian Institute of Technology, New Delhi, India; 21," J. Environ. Prot. (Irvine,. Calif)., vol. 2, pp. 1274-1283, 2011.

[20] P. Setiawati, "No TitlePengaruh Ruang Terbuka Hijau Terhadap Iklim Mikro (Studi Kasus Kebun Raya Cibodas, Cianjur),” 2012.

[21] R. Johansson, E. Emmanuel, "The influence of urban design on outdoor thermal comfort in the hot, humid city of Colombo, Sri Lanka," Int. J. Biometeorol., vol. 51, no. 2, pp. 119-133, 2006. 
[22] Sangkertadi, "Peran Kecepatan Angin terhadap Peningkatan Kenyamanan Terms Manusia dl Lingkungan Beriklim Tropis Lembab, (The Role of Wind Velocity on Increasing Human Thermal Comfort in Hot and Humid Environment)," J. Mns. DAN Lingkung., vol. 13, no. 2, pp. 71-89, 2006.

[23] Sangkertadi, "Pengaruh Kecepatan Angin terhadap Tingkat Kenyamanan Termal di Ruang Luar Iklim Tropis Lembab," J. Lingkung. Binaan Indones., vol. 1, no. 2, 2012.
[24] I. G. A. Hadi, Rohman. Arthawalila, Komang. Gunadi, "Evaluasi Indeks Kenyamanan Taman Kota (Lapangan Puputan Badung I Gusti Ngurah Made Agung) Denpasar," E-Jurnal Agroekoteknologi Trop., vol. 1, no. 1, pp. 2301-6515.

[25] M. Laurie, Pengantar Kepada Arsitektur Pertamanan (terjemahan). Bandung: Intermata, 1986.

[26] Rushayati, "Model Kota Hijau di Kabupaten Bandung Jawa Barat," Institut Pertanian Bogor, Bogor, Jawa Barat. 